Pamiętnik Literacki 2012, 3, s. 23-33
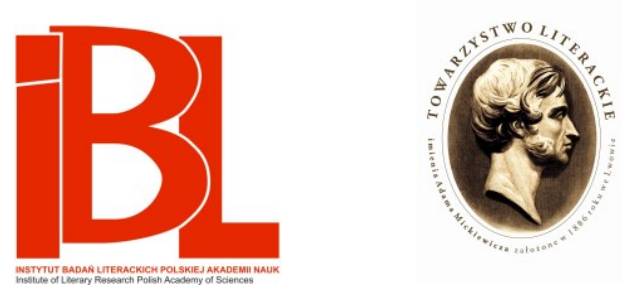

Portrety Juliusza Słowackiego w prozie biograficznej 1945-1981

Ewa Szczepkowska 
EWA SZCZEPKOWSKA

(Uniwersytet Warmińsko-Mazurski, Olsztyn)

\section{PORTRETY JULIUSZA SŁOWACKIEGO W PROZIE BIOGRAFICZNEJ 1945-1981}

W zbiorowej wyobraźni autor Kordiana wygląda jak na znanym stalorycie Jamesa Hopwooda, który w tej formie utrwalił w 1849 roku rysunek lub może akwarelę Józefa Szymona Kurowskiego z 1839 roku. Ten wizerunek przewyższył swoją popularnością podobiznę Słowackiego na medalionie Władysława Oleszczyńskiego. Sam bohater wizerunku dzielił się jednak z matką w korespondencji wątpliwościami co do jego wierności. Pisał, iż nie jest to portret, jakiego by oczekiwał, ,albowiem coś ma na wyrazie srogiego i oczu [...] wyraz niedobrze w nim oddany" ${ }^{1}$.

Te wątpliwości podtrzymuje również opinia jednego z najlepiej znających Słowackiego ludzi - Zygmunta Szczęsnego Felińskiego:

Rysy tego portretu są dość podobne, ale wyraz źle uchwycony i cała postawa niezgodna z prawdą. Wieszcz wygląda tu jak silnie zbudowany, słusznego wzrostu mężczyzna, z małą stosunkowo głową na szerokich ramionach, gdy rzeczywiście inaczej było ${ }^{2}$.

Samemu zainteresowanemu podobał się zupełnie inny konterfekt, nie zdobył on jednak uznania ani u współczesnych mu, ani u potomności. Ale i tu napotkamy sprzeczne reakcje. Płótno malowane w Dreźnie, w lipcu 1831, przez Tytusa Byczkowskiego, zostało zamówione dla matki:

Kochana mamo, kazałem dla Ciebie zrobić mój portret, już jest prawie skończony, w bardzo ładnym guście - przed wyjazdem z Drezna przyszlę go Mamie [...]. Jak mi miło będzie, jeżeli kochanej Mamie zrobi jaką przyjemność 3 .

Opinia Słowackiego, być może pod wpływem krytyki jego wuja, malarza Teofila Januszewskiego, uległa jednak zmianie, gdyż w odpowiedzi na list matki poeta orzekł: „teraz nie mam ani ciężkiego odetchnienia, ani obłąkanych oczu”, niemniej pisał o „źle zrobionym, ale podobnym bardzo portrecie” 4 .

Rysy twarzy portretowanego nie przypominają prawie w niczym stalorytu Hopwooda. Wspólne są tylko bujne, ciemne włosy i słynny kołnierzyk. Znamien-

1 Cyt. za: H. W i d a c k a, O ikonografii Stowackiego - poety spod znaku Panny w 150 rocznicę śmierci. Na stronie internetowej: www.sztuka.pl (1/2000).

2 Cyt. jw.

3 Cyt. za: D. K u d e 1 s k a, Juliusz Stowacki i sztuki plastyczne. Lublin 1997, s. 63.

4 Cyt. jw. 
ne, że sam poeta bardziej skłania się ku temu „realistycznemu” wizerunkowi niż ku całkowicie „romantycznemu” w konwencjonalnym sensie dziełu Hopwooda. Jak słusznie zauważa Dorota Kudelska, autorka książki Juliusz Słowacki i sztuki plastyczne, portret Byczkowskiego najbardziej przypomina późniejszy, niestety zaginiony rysunek z 1836 roku, przypuszczalnie wykonany przez Jana Seweryna Kaniewskiego, wyobrażający poetę w ,greckiej” czapeczce, co dodatkowo uwiarygodniałoby ten właśnie wizerunek, odrzucony przez otoczenie Słowackiego i następne pokolenia ${ }^{5}$.

Wydaje się, że jeszcze jeden z obrazów przedstawiających twórcę Kordiana jest ważny, choć znów nie zachowany - portret autorstwa Wojciecha Stattlera z sierpnia 1843, określony przez Jana Zielińskiego jako „gorejący”. Zarówno sformułowania z listów Słowackiego do Stattlera, do matki, jak i słowa samego malarza „wskazują, że Stattler namalował twarz płomienną, gorejącą, a zarazem bolesną" - pisze monografista, dodając:

Jeśli weźmiemy pod uwagę, że tenże Stattler w jednej z kaplic katedry wawelskiej rysami Mickiewicza obdarzył św. Jana Chrzciciela, narzuca się domniemanie, że S[łowacki] wyglądał na jego portrecie jak Chrystus. Kto wie, może do dziś w jakimś krakowskim mieszkaniu wisi ten portret w roli ,świętego obrazu”, z palącą się przed nim, zamiast rzymskiej lampki - elektryczną żaróweczką ${ }^{6}$.

Zieliński przytacza również za Stattlerem opis wyglądu Słowackiego z okresu, kiedy powstawał obraz:

Szczupłej postaci i nadwątlonego zdrowia [...]. Oko zresztą żywe i młode, a w nim spojrzenie przenikliwe, więcej do orła w locie, do wichru, burzy czyniło podobnym. Czoło wysokie, we włosy blond ozdobne, i wąsik mały spajały go z żyjącym światem, a broda tylko nieco naprzód wysunięta, dumą i śmiałością groziła ${ }^{7}$.

W opisie zdziwienie budzi „czoło wysokie, we włosy blond ozdobne”, bo narusza jeden z podstawowych parametrów wyglądu Słowackiego - wizerunek bruneta z kręconymi czarnymi włosami, spopularyzowany przez wizję plastyczną Kurowskiego-Hopwooda.

Czy to tylko pomyłka malarza?

Niekoniecznie, można bowiem powołać się na relację Jana Lechonia, który uczestniczył w ekshumacji ciała poety na cmentarzu Montmartre w 1927 roku, wiernie powtórzonej w Rymkiewiczowskiej encyklopedii: „Włosy wokół czaszki (jak i te leżące obok) były ciemne, ale nie całkiem ciemne - szatynowe"8.

A zatem - nie brunet, lecz szatyn.

W efekcie dekonstrukcji ikonografii autora Beniowskiego liczba elementów stałych, powtarzających się ulega znacznej redukcji - pozostaje zaledwie „kołnierzyk" Słowackiego i wysokie czoło. Ale i tutaj znajdziemy poszlaki kwestionujące ten, wydawałoby się, absolutnie niepodważalny rys wizerunku. W jednym z haseł encyklopedii o Słowackim Rymkiewicz opisał interesujący szczegół związany z ekshumacją czaszki poety:

\section{Ibidem.}

6 J. Z i e 1 i ń s k i, SzatAnioł. Powikłane życie Juliusza Stowackiego. Warszawa 2000, s. 238.

7 Ibidem.

8 J. M. R y m k i e w i c z, Czaszka Stowackiego. Hasło w: Stowacki. Encyklopedia. Warszawa 2004, s. 75. 
Gdy czaszkę wydobyto z grobu, zajął się nią specjalista, prawdopodobnie jakiś antropolog - był to Francuz, profesor występujący pod nazwiskiem Papilant. Ów Papilant [...] oczyścił czaszkę z włosów, a następnie przeprowadził pomiary. [...] Pomiar taki pozwolił podobno stwierdzić, że czaszka Słowackiego była „większa od normalnej”"

Jeden z pewników wyglądu poety zyskiwałby w ten sposób wiarygodność, nie jest wszakże wcale oczywiste, że taki był prawdziwy wynik pomiarów. Albowiem, jak opowiada dalej Rymkiewicz:

Jan Lechoń, który rozmawiał z Papilantem, napisał [...] po latach (w roku 1955) w swoim Dzienniku, że zdaniem francuskiego profesora czaszka Słowackiego przypominała czaszkę kobiety. $[\ldots],[\ldots]$ powiedział [on], że gdyby nie miał dokumentów, że to czaszka Słowackiego, byłby pewny, że to czaszka kobiety" ${ }^{10}$.

Czaszka kobiety jest z reguły lżejsza i mniejsza od męskiej, trudno więc sądzić, aby francuski antropolog utrzymywał, iż czaszka Słowackiego była „większa od normalnej", a jednocześnie - że miał czaszkę kobiety.

Zdaniem Rymkiewicza, tajemnica czaszki Słowackiego pozostaje do dzisiaj niewyjaśniona.

Wielokrotnie analizowana ikonografia Słowackiego stanowi tylko punkt wyjścia do rozważań nad innymi portretami poety. Wydaje się jednak, że właśnie losy plastycznego wizerunku autora Króla-Ducha są dobrą parabolą i rodzajem metaforycznego skrótu jego literackich portretów. Nieuchwytność i proteuszowość, swoista „migotliwość” tej postaci sprawia, iż na końcu wszystkich „detektywistycznych” procedur pozostaje w ręku badacza ledwie „pukiel włosów i kołnierzyk”, a wyobraźnia zbiorowa karmi się wizerunkiem, którego „rysy [...] są podobne, ale wyraz źle uchwycony i cała postawa niezgodna z prawdą”. Może zatem najbliższy prawdy, zarazem zaś w pełni świadomy piętrzących się przed biografistą Słowackiego trudności, był Julian Wołoszynowski - autor pierwszej w Polsce vie romancée o poecie ${ }^{11}$ - który zarówno jego życie, jak i wizerunek tak odrealnił, że w istocie zdematerializował, co naraziło książkę na niesłuszne zarzuty wykreowania „żywota urojonego i poronionego", choć ta właśnie wizja zjawiskowego Słowackiego metaforyzuje już w punkcie wyjścia problemy z jego literackim obrazem.

Przejdźmy zatem do prezentacji wizerunku Juliusza Słowackiego w biograficznej beletrystyce okresu 1945-1981, a może przede wszystkim do ideologicznych „użyć” tego wizerunku, jak również efektów owych opisów, jakkolwiek sens takiego przedsięwzięcia budzić winien spore wątpliwości, gdyż w większości wypadków są to teksty o wartości głównie historycznej. Trudno jednak z góry wyrokować o wynikach tego „remanentu” peryferii polskiej literatury, nie wyklucza on bowiem możliwości rewitalizacji zarówno zapomnianych utworów, jak i zmarginalizowanych autorów.

Prezentowane teksty są $\mathrm{w}$ istocie raczej dokumentem okresu, w którym powstały, niż dziełami o uniwersalnej wartości. Nie oznacza to jednak oskarżenia o myślowe ubóstwo epoki, bo problem wydaje się bardziej złożony. Trudno do końca rozstrzygnąć, czy odpowiedzialnością za taki stan rzeczy należy obciążyć epokę, a nie np. gatunek literacki bądź, co też jest możliwe, specyfikę opisywane-

9 Ibidem.

10 Ibidem, s. 76.

${ }^{11}$ J. Woło s z y n o w s k i, Stowacki. Powieść. Wstęp S. Wa s y le w s k i. Poznań [1929]. 
go obiektu, którego „nieuchwytność” oddaje historia plastycznych reprezentacji „twarzy” Słowackiego. Niewykluczone również, że przyczyna tkwi w narodowych cechach polskiej biografistyki jako determinantach niskiej atrakcyjności literackiego wizerunku poety czy też w pośledniej roli kopciuszka, którą biografistyka stale odgrywa. A z postacią autora Fantazego radziły sobie nie najlepiej także inne epoki.

Chociaż szersze ujęcie problemu wizerunków Słowackiego w literaturze wspomnianego okresu stanowi nie lada pokusę (poza kręgiem rozważań znajduje się niezwykle istotny i przełomowy w sposobie myślenia oraz pisania o romantycznym twórcy esej Rymkiewicza, a także ciekawy, o prowokującej wymowie, dramat Mariana Pankowskiego Nasz Julo czerwony, antycypujący niektóre współczesne wątki w refleksji nad Słowackim), to konieczna była jednak selekcja i wyodrębnienie tekstów względnie jednorodnych gatunkowo, zawierających się w formule, którą w polskim literaturoznawstwie Andrzej Makowiecki określił jako „powieść o artyście" ${ }^{2}$. Encyklopedyczna wiedza na temat tego subgatunku potwierdza, że w literaturoznawstwie zachodnim występują bardziej adekwatne terminy: niemiecki „Künstlerroman”, angielski „,novel concerning an artist”, „portrait of the artist novel" lub ,artist novel”. Warto wziąć pod uwagę określenie „portrait of the artist novel”, które uzasadnia również, dlaczego wśród egzemplifikacji pojawia się Portret Słowackiego Pawła Hertza, gatunkowo złożony i trudny do zaklasyfikowania jako powieść. Takiej propozycji, wymijającej klasyczną typologię literackiej biografistyki skonstruowaną przez Marię Jasińską, można postawić zarzut nadmiernej ogólności, dlatego spróbuję skojarzyć to ujęcie z dokładniejszą analizą genologicznego kształtu przywoływanych utworów, niemniej jednak to właśnie ,portret” stanowi definicyjny trzon.

Sam termin jest elastyczny i pojemny, obejmuje przynajmniej trzy typy narracji: portret fikcyjnego twórcy (np. Portret Doriana Graya Oskara Wilde'a), portret syntetyzujący, który odnosi się do biografii jednej lub kilku realnie istniejących postaci, ale modyfikuje ich życiorys wedle intencji autora (Jan Krzysztof Romain Rollanda czy arcydzieło gatunku, Doktor Faustus Thomasa Manna) i wreszcie literacki portret autentycznego twórcy przywołujący konkretną biografię - tu można wymienić liczne przykłady vie romancée. Wszystkie narracje o Słowackim należą do tej trzeciej odmiany. Zarysowany na początku wątek ikonograficzny pozwoli dodatkowo zróżnicować te opowieści i poza wyzierającym z nich kontekstem historycznym wydobyć ludyczny aspekt gry z wizerunkiem Słowackiego.

\section{Impresja}

Od wspominanej już pierwszej w Polsce vie romancée Wołoszynowskiego, której bohaterem był Słowacki, rozpoczyna się historia tego subgatunku. Opublikowana w 1929 roku książka nie tylko wprowadzała do literatury okresu międzywojennego szeroko znaną na zachodzie Europy modę literacką, ale stanowiła też przejaw poszukiwania własnej oryginalnej formuły pisarstwa na pograniczu poezji i prozy, wyłamującego się z naśladownictwa wzorców stworzonych przez Lyttona

12 A. Mak ow i e c k i, Młodopolski portret artysty. Warszawa 1971. 
Stracheya, André Maurois, Irvinga Stone'a czy Lionela Feuchtwangera. Z europejskich modeli powieści o artyście stosunkowo najbliższa Wołoszynowskiemu mogłaby być biograficzna proza Stefana Zweiga. Wołoszynowski, kształtując swą powieść w relacji z innymi tworzywami: muzycznym, plastycznym, kontynuował ujętą w subiektywizująco-impresjonistyczny ciąg epizodów z życia poety jego wizję z poprzedniej epoki - mistrza nastroju, zwolennika jedności sztuk i estetyzacji rzeczywistości, ukazywał Słowackiego wystylizowanego i upozowanego na bohatera utworów romantycznych. Poetyckość i ekspansywna literackość uznana za mankament tej prozy, przeświecającej, jak zauważyli krytycy, „,przebłyskami własnych światów duchowych", jest w istocie jej zaletą, opatruje bowiem literacki wizerunek Słowackiego indywidualizującą sygnaturą poety. Trafnie ów portret romantycznego artysty sumował Makowiecki:

Wołoszynowski rozdźwięczył tylko jedną strunę, strunę Godziny myśli, W Szwajcarii, Anhellego. [...] W powieści jego na tle pejzaży, które wyczarować mógł tylko prawdziwy poeta, [...] z daleka przesuwa się niby zjawa ,jak sen jaki złoty” blady cień Słowackiego. Czy zbliżyliśmy się do niego? Pewnym jest, żeśmy się nie oddalili ${ }^{13}$.

Pokoleniowy rezonans w okresie międzywojennym zyskała Kleinerowska monografia - rodzaj narodowej hagiografii, i te właśnie dwa tak różne „żywoty” Słowackiego stały się dla kolejnych czytelników biografii poety negatywnym punktem odniesienia.

\section{Portret „klasycyzujący”}

Następny „rozdział” w narracjach biograficznych o Słowackim napełnia się bardzo konkretną treścią za sprawą książek kuźniczan: Pawła Hertza i Mieczysława Jastruna ${ }^{14}$, tworzących jedną z najbardziej popularnych w realizmie socjalistycznym odmian narracji historycznej z wybitną jednostką lokowaną na szerokim kulturowo-społecznym tle. Popularność opowieści biograficznych Stanisława Czernika o Janickim, Jerzego Broszkiewicza o Chopinie, Jastruna o Kochanowskim czy Mickiewiczu można tłumaczyć kontynuacją przedwojennej mody na zbeletryzowaną biografię, ale przede wszystkim łatwością kreowania wzorców i funkcji dydaktycznych oraz atrakcyjnością przekazu znacznie większą niż w wypadku biografii naukowej. Nie sposób pominąć też roli tej wypowiedzi w ówczesnym literaturoznawstwie: po pierwsze, stanowiła ona ekwiwalent życiorysów naukowo opracowywanych w myśl zasad marksistowskich, po drugie - uzupełniała badania historycznoliterackie. Prym wiodła tu biografistyka literacka poświęcona Mickiewiczowi jako autorowi o „większym zmyśle historycznym”, ale nie zapomniano także o Słowackim ${ }^{15}$.

Obie książki pomimo chronologicznej bliskości publikacji - Hertza: 1949, Jastruna: 1951 - dzieli data Zjazdu Szczecińskiego. Trudno jednak ten fakt mitologizować, gdyż obie pozycje były w pierwszej połowie lat pięćdziesiątych kilka-

${ }^{13}$ Cyt. za: K. M e lo c h, Portret urojony czy rzeczywisty. „Nowe Książki” 1958, nr 15.

${ }^{14}$ P. Hert z, Portret Stowackiego. Warszawa 1949. - M. J a s tr u n, Spotkanie z Salomea. Warszawa 1951.

${ }_{15}$ Zob. M. Z a w o d n i a k, Jak beletrystyka torowata droge marksistowskiej nauce. W zb.: Socrealizm: fabuty, komunikaty, ikony. Red. K. Stępnik, M. Piechota. Lublin 2006. 
krotnie wznawiane, a kolejne wydania Portretu Słowackiego nie przynoszą żadnych redakcyjnych zmian. W dyskusji wokół książki Hertza, jedynego opublikowanego w jubileuszowym roku syntetyzującego ujęcia życiorysu Słowackiego, szermowano różnymi określeniami gatunkowymi: „powieść”, „omówienie monograficzne”, „opowieść”, „portret biograficzny”, ale kwestię terminologii stosowanej do tego typu prac w tamtej epoce cechuje duża dowolność ${ }^{16}$. Zarówno powściągliwy styl książki Hertza, jak i przywołana tradycja gatunku stanowiły w jakiejś mierze pochodną związków pisarza z racjonalistycznym programem Kuźnicy, o podłożu pozytywistyczno-oświeceniowym, i formę kontynuacji działalności krytycznoliterackiej na łamach periodyku, w którym szkice o Stendhalu, Chamforcie czy Prouście inspirowane były tradycją Le Bruyere'a i Sainte-Beauve'a. Charakterystyczne dla kuźniczan dążenie do reinterpretacji romantyzmu i rewizji biografii romantycznych prowadziło do ,przepisania” życiorysu z obowiązkowym dla tego okresu „obrazem dziejów” i epoki. W rezultacie powstała książka hybrydalna, popękana wewnętrznie i problematyczna w gatunkowej kwalifikacji sygnalizowanej w tytule. Podstawową bowiem zasadą portretu jest nić sympatii łącząca autora i bohatera. Zdaniem Andrzeja Stanisława Kowalczyka:

Portret cechuje paralelizm dwóch przedstawień: portretowanego i portrecisty. W efekcie powstaje tekst o przyjaźni, fascynacji, przywiązaniu łączącym te dwie postaci. W portrecie bowiem, podobnie jak w eseju, obowiązuje zasada sympatii. Portret kogoś, kogo portrecista nie akceptuje lub nie rozumie, staje się karykaturą, pamfletem ${ }^{17}$.

W książce Hertza ta nić sympatii wije się dość kapryśnie, ujawniając niekiedy ironiczną postawę narratora i rodzaj nadmiernie zdystansowanego oglądu opisywanego obiektu. Z kolei niekonsekwencje Hertzowskiej opowieści o Słowackim w sferze ideologicznej wywołały zarzuty stanowczo niewystarczającego wykazania postępowości Słowackiego. Tytuł recenzji Jastruna: Ariel w podróży, dokładnie tłumaczył przyczynę - wydobyte przede wszystkim rysy dandysowskiego i bajronicznego poety, głęboko zanurzonego w „świat glansowanych rękawiczek” i „,woskowanych parkietów”. Zdaniem recenzentów, Hertz zbyt dyskretnie ukazał linię rozwoju Słowackiego ku postawie rewolucyjnej, postawie kogoś, ,kto wielbił postępowy ruch dziejów” i umiał „myśleć dialektycznie”, dał natomiast portret artysty nadmiernie ulegającego modom epoki. Jeśli przyjąć punkt widzenia ówczesnych recenzentów, nie dziwi zasadność tych zarzutów; zamiast oczekiwanej „,nowej twarzy” Słowackiego - ,pomocnika rewolucji nieuniknionej”, Hertz zaproponował jakiś rodzaj kontynuacji portretu Kurowskiego-Hopwooda.

\section{„Święty" rewolucjonista}

Rekompensatą za ów niedostatek postępowości miała się stać powieść biograficzna Jastruna Spotkanie z Salomeą z 1951 roku. Jego zainteresowanie Słowackim

${ }^{16}$ Zob. m.in. M. J a s tru n, Ariel w podróży. „Kuźnica” 1949, nr 37. Przedruk w: Wizerunki. Szkice literackie. Warszawa 1956. - H. M a rk i e w i c z, „Portret Stowackiego”. „Odrodzenie” 1949, nr 36. - T. M i k u l s k i, rec.: P. H e r t z, Portret Stowackiego. „Zeszyty Wrocławskie” 1949, nr 3/4. Przedruk w: Miniatury krytyczne. Warszawa 1976.

17 A. S. K o w a 1 c z y k, Nieśpieszny przechodzień i paradoksy. Rzecz o Jerzym Stempowskim. Wrocław 1997, s. 230. 
poza ramami socrealizmu zaistniało w nieco późniejszej eseistyce pisarza, stanowiącej rodzaj rozważań na temat wyobraźni, urazów i kompleksów poety, w czym można by widzieć zarówno kontynuację tradycyjnych ujęć, jak i zapowiedź inspiracji psychoanalitycznej w badaniach nad romantycznym twórca, reprezentowanej np. przez Laseczke dandysa i płaszcz proroka Ewy Łubieniewskiej. Natomiast uderzającą cechą Spotkania z Salomea, pomimo pozornie oczywistej formuły powieści biograficznej, jest swoista hybrydalność. Z jednej strony, Jastrun - pisarz o znacznej świadomości literackiej, podobnie jak Hertz, sięga do najlepszych wzorców biografistyki literackiej. Już pierwsze sceny odsyłają poprzez kameralny nastrój i tonację, która wynika w dużym stopniu z przyjętej konwencji „,spotkania po latach", do ironiczno-rewizjonistycznej powieści Thomasa Manna o Goethem, Lotta $w$ Weimarze. Z drugiej strony - wymogi ideologiczne, jakie narzucił sobie autor, ograniczają możliwości tak obiecująco zarysowane w punkcie wyjścia.

Tytuł zapowiada wątek prywatny, a więc również występowanie elementów psychologii, jednak powieściowy życiorys Słowackiego podporządkowany został zasadzie socrealistycznego „Bildung”, fabularnemu schematowi obrazującemu „proces przechodzenia bohatera od niewiedzy i niedojrzałości do uświadomienia i ideologicznej dojrzałości" ${ }^{18}$.

Spotkanie z Salomea rozpoczyna praktykę stosowaną przez innych biografistów Słowackiego. Właściwie tylko Portret Słowackiego Hertza kreśli „bezpośredni” wizerunek autora Beniowskiego. Kolejne narracje biograficzne, podobnie jak książka Jastruna, są portretami „zapośredniczonymi”; Słowacki przegląda się w oczach ,innych" niczym w lustrach. Tak więc w powieści Stefana Flukowskiego ujrzymy poetę tak, jak postrzegał go Norwid, a w powieści Jana Dobraczyńskiego pojawia się punkt widzenia Felińskiego. Jeśliby uwzględnić bardzo już osobliwy ,portret” Słowackiego, jaki ewentualnie można zobaczyć w fantastyczno-historycznej wizji Teodora Parnickiego włączonej w Muzę dalekich podróży, książkę stanowiącą rodzaj historycznej political fiction, to „zapośredniczenie” tworzy już charakterystyczny dla tego autora system zwielokrotnionych luster. W dramacie Pankowskiego Nasz Julo czerwony oglądamy z kolei Słowackiego poprzez medialne narzędzia współczesnej kultury masowej.

A zatem Słowacki jest u Jastruna przez ,innych” nie tylko oglądany, ale również kształtowany, formowany i reedukowany; występuje w roli ucznia, człowieka zagubionego i zdezorientowanego, który „Przepych swej wyobraźni rzucał na pożarcie obłędowi mistycznemu" ${ }^{19}$. Kontakt z bohaterami postępowymi: Zofią Mielęcką, Kajetanem Węgierskim, a zwłaszcza z pułkownikiem Krysztofowiczem, zostaje uwieńczony sukcesem i wolą poszerzenia kręgu agitatorów Gromady Grudziąż z jej utopijno-komunistyczną ideologią.

Jastrun epizod Wiosny Ludów czyta poprzez współczesność, zarazem wpisując w nią postawy bohaterów. Refleksje Słowackiego „na paryskim bruku” dotyczące braku oddźwięku jego poezji i izolacji w burżuazyjnej stolicy korespondują z postawami pasywnych, wyalienowanych, malkontenckich inteligentów z socrealistycznej prozy. Pożądaną zatem biografią Słowackiego steruje ,rewolucyjna

18 W. To m a s i k, Polska powieść tendencyjna 1949-1955. Wrocław 1988, s. 130.

19 J a s tr u n, Spotkanie z Salomea, s. 69. 
romantyka”: poeta łamie pióro i decyduje się „,rzucić ten czar malowany słowami dla pracy nad doskonaleniem świata już istniejącego" ${ }^{20}$.

Jeśli Hertzowi w Portrecie Stowackiego bliska była romantyczna dandysowska wizja Hopwooda, to Jastrun zmierzał chyba ku zaginionemu Stattlerowskiemu „gorejącemu” wizerunkowi. „Gorejącemu”, oczywiście, płomieniem nadchodzącej rewolucji, ale i ,gorejącemu” jako „święty obraz" - Chrystusa z bolesną twarzą. W Spotkaniu z Salomea znajdziemy zresztą stosunkowo dużo opisów wyglądu Słowackiego - najciekawsze wydają się te, w których postrzegany jest on przez Salomeę; pojawia się wtedy w nich rys prywatny, intymny i właśnie ten „święty”, który miał wyróżniać portret Stattlera:

Jaką ten Julo ma twarz poważną, jak bardzo wychudzoną. [...] Nic z drapieżności młodzieńczej, drapieżności, którą on swego czasu wyostrzał w sobie, hodował, aby być w stylu bohaterów romantycznych. Głębokie cienie pod oczami, które pozostały aksamitne, piękne, ale i doły wykopane w twarzy, doły, których nie było, gdy wtenczas nagle, nie oglądając się na nic, wyjechat ${ }^{21}$.

\section{Miniatura}

Za swoistą reakcję na „postępowy” wizerunek Słowackiego można uznać wydaną w 1959 roku mikropowieść Płomień róży Stefana Flukowskiego, którego postawa twórcza z okresu międzywojennego wskazywała na zainteresowanie zwłaszcza późnymi dziełami Słowackiego, co ujawniało się w konstruowaniu obrazów poetyckich inspirowanych Królem-Duchem, przepracowanych jednak w oparciu o założenia racjonalistycznej Awangardy krakowskiej. Jest to książka niedoceniona i niesłusznie zapomniana. W tym „,magicznym zwierciadle poetów” aktywność wyobraźni autora Czarnych kwiatów rozpoczyna pasmo wspomnień-wizji z życia Słowackiego, stylizowanych rokokowo, gotycyzująco, baśniowo czy groteskowo, i przesuwających się w rytmie przyspieszonej projekcji filmowej. Wykreowana wspólnota poetów jako wypadkowa zestawienia trzech indywidualności poetyckich: Norwida, Słowackiego i autora Płomienia róży, stanowi świadectwo oddziaływania wizyjnej poezji Słowackiego na inwencję współczesnego twórcy, a zarazem czyni romantycznego wieszcza patronem i prekursorem surrealistycznej poezji w XX wieku. Niewielka powieść Flukowskiego dąży do przełamania nie tylko dotychczasowych wizerunków Słowackiego, ale również konwencji w prozie biograficznej; jednocześnie odpowiada formule literackiego portretu artysty, tym bardziej że tworzy jej nowy wariant: niewielki rozmiar, plastyczno-wizyjny kształt, specyficzny sposób obrazowania z charakterystyczną dlań zmiennością tonacji emocjonalnej - od funeralnej po groteskową, przynosi efekt genologicznej miniatury.

Powieść Flukowskiego jest niewątpliwie próbą przerwania powtarzalności i monotonii schematów biograficznych, w jakie ujmowany był życiorys Słowackiego. Próbą nie do końca konsekwentną, gdyż autor mimo wszystko podąża przetartym szlakiem, wybierając konwencjonalne elementy tego życiorysu. Po dandysie-inteligencie z litografii Hopwooda u Hertza, „świętym” stattlerowskim rewolucjoniście u Jastruna otrzymujemy dzięki lejtmotywowi w tej powieści -

\footnotetext{
20 Ibidem, s. 164.

21 Ibidem, s. 90.
} 
ruchowi anielskich skrzydeł symbolizujących poetyckie natchnienie - jakiś rodzaj odpowiednika archetypu poety z medalionu Oleszczyńskiego, ale z figlarnym amorkiem Rustema w tle. A realizmem szczegółu Flukowski antycypuje znakomite osiągnięcia Rymkiewiczowskiej mikrologii.

Płomień róży zapowiada zarazem próbę rewizji szeregu schematycznych wizerunków, z jaką mamy do czynienia w kilku tekstach z lat sześćdziesiątych i początku siedemdziesiątych. Odbywa się ona metodą pośrednią, za pomocą konstruowania biografii alternatywnych, innych wariantów losów poety.

\section{Portrety wirtualne}

Kazimierz Wyka w znanym eseju Wyznania uduszonego z 1961 roku obok skorygowanych życiorysów Mickiewicza i Kraszewskiego proponuje także inny wariant biografii Słowackiego, mieszkańca Podhala, autora symbolistycznych wierszy i wzorowego filologa, z pasją porządkującego własną spuściznę, o czym informuje wirtualny list do Karola Szajnochy:

Porządek w piśmie dla potomnych przekazywanym jest niezbędny jak porządek w rubrykach u bankiera, ażeby wiedział, z czego ma się wypłacić, a gdzie nie sięgają kapitały jego ${ }^{22}$.

Autor innego wizerunku, Jalu Kurek, tym razem nie klimatowi, ale torakochirurgii przypisuje możność wydłużenia życia Słowackiego o 23 lata, mianuje go pierwszym wieszczem, przywódcą demokratycznego nurtu powstania styczniowego, a nawet zaprasza go w fantastyczną podróż do Polski Ludowej jako wodza nowej awangardy, ,płomiennego trybuna” i autora antymistycznego Króla-Ducha.

Wreszcie w najobszerniejszym z tych fantastycznych „portretów”, w Muzie dalekich podróży Parnickiego - alternatywnej historii powstania listopadowego, w którym zwyciężają Polacy (taki wariant polskiej historii rozważa w poezji także Słowacki) - Mickiewicz zostaje ministrem kultury i religii i wydaje zakaz włączenia do szkolnych podręczników utworów Słowackiego, Krasiński wyjeżdża jako ambasador do Petersburga, a Słowacki musi opuścić kraj i udać się na emigrację do Meksyku. Znów mamy do czynienia, podobnie jak u Flukowskiego, ze wspólnotą losów autora i jego bohatera. Meksyk to przecież miejsce emigracji również Parnickiego.

Te futurologiczne eksperymenty z biografią poety, bliższe formule ,autoportretu", więcej mówią, oczywiście, o samych piszących niż o charakteryzowanym obiekcie i ta cecha łączy je z prezentowanymi tu wcześniej książkami o autorze Kordiana. Fantazja Jalu Kurka jest po prostu ekspresją jego sympatii dla rewolucyjnego Słowackiego, alternatywna ,profesorska” biografia poety skonstruowana przez Wykę służy celom historycznoliterackim - sugeruje pośrednie, romantyczne jeszcze ogniwo w rozwoju polskiego symbolizmu, jakkolwiek może też być echem przygotowywania projektów tatrzańskiego grobowca Słowackiego z początków XX wieku. Z kolei Parnicki umieszcza poetę w kilku kontekstach, zarówno własnego życiorysu, jak i odwołań do innych swoich utworów, czyniąc zeń kogoś, kto podziela jego los i koncepcje historiozoficzne.

Jaka natomiast książka zamyka ów ciąg literackich wizerunków Słowackiego?

${ }^{22}$ K. Wy k a, Wyznania uduszonego. Kraków 1995, s. 205-206. 


\section{Karykatura}

Jan Dobraczyński ukończył powieść Pacierz, co płacze, i piorun, co błyska 29 lipca 1981 (w dzień Zatroskanej Marty - jak sam podkreśla). Dwudzielna struktura książki sytuuje Słowackiego w obliczu dwóch podstawowych wydarzeń historycznych - powstania listopadowego i Wiosny Ludów (powstania wielkopolskiego). Epizod 1848 roku jest rodzajem lustrzanego odbicia tego samego wydarzenia ze Spotkania z Salomea, tyle że rolę utopijno-komunistycznych edukatorów przejmuje tutaj Feliński, autor Beniowskiego zaś nawracany jest nie ku ideom rewolucyjnym, ale katolicko-narodowym, antycypującym ideologię narodowej demokracji. Na tle tradycyjnej kanwy polskiego losu, usankcjonowanego przez romantyzm jako udział w powstaniach XIX-wiecznych, aż po ruch solidarnościowy, w który to wątek wpisana została rola patriotycznego poety, dzielącego z narodem bóle, zarysowuje się postawa ugody, współpracy i porozumienia z zaborcami oraz wierności Kościołowi katolickiemu.

Redukcja postaci Słowackiego (również w sensie dosłownym, fizycznym) postępuje w tej dziwnej powieści dalej niż u Jastruna, u którego poeta podejmuje jednak jakieś próby dialogu ze swoimi dyskutantami. Słowacki Dobraczyńskiego jest całkowicie bezradny i pasywny, odgrywa przede wszystkim rolę statysty wobec dziejącej się historii, a głównym bohaterem utworu stopniowo staje się Zygmunt Szczęsny Feliński. W pierwszej części Dobraczyński wielokrotnie podkreśla fizyczną słabość Słowackiego i jego „karlą sylwetkę”:

Mały i drobny, był niesiony przez thum niby korek przez morską falę. [...] Gdy znalazł się na podwórzu, chwycił go za ramię jakiś podoficer:

- Umiesz, mały, nabijać? - zapytał.

- Nie.

- To chodź, pokażę ci.

Próbował zasłonić się bagnetem, ale żołnierz chwycił karabin za lufę. Wysunąwszy nogę ze strzemienia kopnął Juliusza w pierś. Słowacki puścił karabin, zatoczył się, [...] osunął się na bruk. Żołnierz [...] zamierzał uderzyć leżącego kolbą. Oficer powstrzymał go:

- Zostaw tego zdechlaka! Zachciało się takiemu wojować!

- Nie, panie Słowacki - oświadczył oficer - nie weźmiemy cię. Jesteś za mały. Wyglądasz jak chłopiec ${ }^{23}$.

Niski wzrost i słabowitość Słowackiego są w efekcie głównym rysem tego literackiego portretu i nie znajdują w powieści żadnej rekompensaty, bo w jego geniusz poetycki każe Dobraczyński wierzyć raczej na słowo, w myśl konwencji i tradycji, nie potwierdza się on w literackiej materii utworu. Pewne novum stanowi wprawdzie, nie wykorzystany w dotychczasowych biografiach, obraz Słowackiego jako poety-żołnierza, lecz jest to żołnierz - jak wynika z przytoczonych przykładów - „niewydarzony”, niespełniony. Realizuje się on dopiero w chwili śmierci, ale niezmiernie wysokim kosztem - swoistego samounicestwienia, zaprzeczenia i wyparcia się własnej twórczości. Umierający Słowacki zwraca się do Felińskiego, który próbuje skłonić go do położenia się do łóżka:

23 J. D o bra c z y ń s ki, Pacierz, co płacze, i piorun, co błyska. Warszawa 1983, s. 68, 80, 105. 

w łóżku..

- Nie - głos Słowackiego był tylko szeptem. - Nie... Chcę... widzisz... jak żołnierz... nie

Po czym Feliński mówi:

Gdy byłeś z księdzem, przeglądałem twój poemat. Ileż niezwykłych myśli, Julku... Chciałeś poprawiać...

Słowacki zrobił lekceważący ruch dłonią.

- Już nie... To tylko słowa... to nie to...24

A zatem historia literackich portretów biograficznych Juliusza Słowackiego w latach 1945-1981 zatacza koło. To, co ją zamyka, jest rodzajem powrotu do początku, choć nie $\mathrm{w}$ formie prostego powtórzenia, lecz groteskowej paraboli sytuacji wyjściowej.

\section{A bstract}

EWA SZCZEPKOWSKA

(University of Varmia and Masuria, Olsztyn)

\section{JULIUSZ SŁOWACKI'S PORTRAITS IN POLISH 1945-1981 BIOGRAPHICAL PROSE}

Starting point of the considerations on Juliusz Słowacki's portraits in biographical prose is a set of the poet's fine arts images. This concept, known in Western literary studies as "Künstlerroman" or "portrait of the artist novel," offers a framework for the presentation of Słowacki's images in 1945-1981 biographical fiction. The first stage of narrations about Słowacki is made up by socialist realism books, namely "classicizing" picture by Paweł Hertz, and Mieczysław Jastrun's Spotkanie $z$ Salomea (A Meeting with Salomea), the latter being an example of the romantic poet's image overuse. Next, Stefan Flukowski's Płomien róży (Flame of a Rose) is an attempt at a revision of Słowacki's traditional picture. By contrast, Jan Dobraczyński's novel Pacierz, co płacze, i piorun, co błyska (Prayer that cries and lightning that flashes) exemplifies an ideological use of Słowacki's picture according to the principles of national democracy.

${ }^{24}$ Ibidem, s. 207-208. 